\title{
Key Currencies After the Euro
}

\section{Citation}

Cooper, Richard N. 1999. “Key Currencies After the Euro." World Economy 22 (1) (January): 1-23. doi:10.1111/1467-9701.00190.

\section{Published Version}

doi:10.1111/1467-9701.00190

\section{Permanent link}

http://nrs.harvard.edu/urn-3:HUL.InstRepos:15754030

\section{Terms of Use}

This article was downloaded from Harvard University's DASH repository, and is made available under the terms and conditions applicable to Other Posted Material, as set forth at http:// nrs.harvard.edu/urn-3:HUL.InstRepos:dash.current.terms-of-use\#LAA

\section{Share Your Story}

The Harvard community has made this article openly available.

Please share how this access benefits you. Submit a story.

Accessibility 
November 1997

\title{
Key Currencies After the Euro
}

\author{
Richard N. Cooper \\ Harvard University
}

\section{$\underline{\text { Introduction }}$}

On January 1, 1999, an as yet unknown number of European countries will introduce a new European currency, the euro, which after $3 \frac{1}{2}$ years will lead to the complete withdrawal of their existing national currencies. This change will represent a bold monetary experiment of unprecedented magnitude. It will require substantial changes both in the execution of day-to-day economic transactions and in the overall functioning of European economies. An enormous amount of effort is being and remains to be devoted to making the change as smooth as possible and to understanding the consequences of the change within Europe.

The rest of the world is largely a bystander in this engaging process. Europeans have shown little interest in the external ramifications of their actions, and few non-Europeans until recently have paid much attention to the dramatic changes that will soon take place within Europe. What will they portend for outsiders, and in particular for the role of the US dollar and other national currencies in the world economy?

The Japanese yen, the German mark, the French franc, the British pound, the Swiss franc, and especially the US dollar are national currencies used extensively in diverse ways by nonnationals around the world. With creation of the euro, the German mark and the French franc will disappear, and possibly, at a later date, the British pound as well. It would be natural for the euro to replace these European currencies in their international roles, although with the initial and inevitable confusions associated with the introduction of the euro that cannot be taken for granted; 
foreigners may take refuge from the turbulence by moving to the dollar, the yen, or other currencies. But creation of the euro raises the possibility that in the longer run it will not only replace the mark and the franc in their international roles, but will also compete more effectively with the dollar and the yen as international currencies, even to the extent of eventually displacing them as well.

Indeed, precisely this specter has been held out recently by Fred Bergsten (1997, and in Masson et al., 1997), and in milder form by Alogoskoufis and Portes (in Masson et al., 1997). Bergsten suggests that within a decade as much as $\$ 1000$ billion now held in foreign currency balances around the world, mainly in US dollars, may shift into euros, with profound consequences for the exchange rate between the dollar and the euro and possibly for macroeconomic performance as well.

This paper will address these various issues. It first takes up the reasons why national currencies might be used internationally, and provides some data on the international role of currencies today, and on their recent evolution. It then takes up the factors suggesting that the euro will emerge as an international currency, possibly displacing the dollar. I then offer reasons for believing that major displacement of the dollar will not take place, at least for several decades. Next it addresses what the consequences might be if that forecast proves to be incorrect. A concluding section touches on probably more important issues that are not discussed in detail in the paper.

\section{International Roles for National Currencies}

The classical roles for money are as a unit of account, a medium of exchange, and a store of value. These roles also have applicability in the international economy. Actually, there are two quite different unit of account functions that a national currency can play. The first is as a 
comprehensible common standard of measurement. There are often occasions in which we want to make international economic comparisons, or even to aggregate economic magnitudes involving two or more countries. We need a common unit of measurement to do this. It could be any commonly agreed measure, even an artificial one, but it is not unnatural to use the currency of the largest national economy. It is noteworthy that the International Monetary Fund now keeps its accounts in a wholly artificial unit, the SDR (defined as a basket of the five leading currencies), but it is incomprehensible to most people outside the specialized community of IMF aficionados, and I conjecture most interested parties outside the IMF itself mentally translate SDR-measured magnitudes into dollars or some other national currency.

The second unit of account function involves denominating assets (e.g. international bonds or consortium loans) or registering trade invoice values or prices of internationally trade commodities -- anything that requires a well-defined monetary specification. Whenever crossborder transactions are involved, at least one party must generally use a currency other than his own. For reasons to be discussed below, two parties may prefer a third currency. But the only way to avoid some international use of national currencies for this purpose would be a regime in which all sales by convention are made in the currency of the seller (or all purchases in the currency of the buyer). Such a convention would stifle much useful international trade in goods, services, and assets.

Logically units of account for invoicing or denomination could be separated from the medium of exchange, and indeed some bonds denominated in a particular currency can be purchased in a variety of currencies. But again it is natural in many cases for the unit of account, if it is a functioning money, to be used also as the medium of exchange. Thus goods invoiced in dollars are 
usually paid for in dollars. So the argument for some international monetary unit of account also applies to its use as a medium of exchange.

Finally, "money" is used as a store of value, at least temporarily. Some limited international use of national currencies in this role flows naturally from their use as a medium of exchange, since parties may want to accumulate over time the currencies they will need to make payments on a specific date, e.g. on an import contract or for interest on an outstanding bond. In addition, monetary authorities accumulate "foreign exchange reserves" to be used to intervene in foreign exchange markets should that prove desirable. It is worth noting explicitly that "money" held as a store of value by business firms or financial institutions is not usually held in the form of money at all, but in liquid interest-bearing assets. This fact will play an important role in the argument developed below. However, many individuals around the world, for diverse reasons, find it expedient to hold monies, i.e. banknotes, from countries other than their own, and the US greenback has become overwhelmingly the favored instrument in most parts of the world.

Why do we see extensive international holdings of national currencies? In principle, people could hold only national currencies; with well-functioning foreign exchange markets they could convert into another currency only at the moment it is needed.

The reasons for holding foreign currencies are many and diverse, but for private parties they boil down to three: market barriers, transactions costs, and liquidity (which on some definitions are included in transactions costs). National exchange controls create an obstacle to currency conversions when needed, particularly if the need is not acceptable to the authorities or if it arises unexpectedly. Transactions costs inhibit transactions, especially reversible transactions or those that can enjoy some offset netting over a period of time. 
Up to a point, transactions costs in financial markets are influenced by the size of the institutions participating in the market and hence, to assure competition, also by the size of the market. That is because of economies of scale in efficient financial management systems (e.g., a given software program, once written, can handle few or many transactions with indifference, but the average costs decline with number of transactions). Many economies are too small to have highly efficient, competitive markets in foreign exchange.

But foreign exchange markets are subject to another, quite different efficiency as a function of use and scale, called network externalities. By analogy with language or the telephone, the more people who use it, the more useful it is to any single user. My ability to communicate by phone or fax beyond a circle of known acquaintances depends on how many of the parties I potentially might want to communicate with have telephones and fax machines. The value of a telephone to me depends on how many other potential respondents have phones. My ability communicate with strangers hinges on finding a common language of communication. Polyglot Chinese use Mandarin in China; polyglot Indians and Nigerians use English within India and Nigeria.

The network externality in financial markets concerns mainly liquidity: the ability to carry out a transaction whenever I want to carry it out without incurring extra cost. Liquidity will generally be higher the higher the number of transactions -- the "thicker" the market. This phenomenon is present in foreign exchange markets -- accounting for the fact that many international transactions between two countries other than the United States involve intermediation through US dollars rather than direct exchange of the two currencies involved. Transactions costs will be lower, but they will be lower mainly because of the larger number of transactions of each currency with the US dollar than between the two currencies, resulting in lower bid-ask spreads. 
The phenomenon is also present in securities markets, thus influencing which securities people will want to hold as a temporary store of value to meet unpredictable needs. In particular, the market in US Treasury securities is unrivalled in this regard.

\section{National Currencies in the World Economy}

The various functions of money can all be observed in the international use of national currencies. Organized commodity markets are almost universally reported and traded in US dollars, and many off-market transactions use these market prices. Foreign trade other than commodities is often denominated in currencies other than those of the exporting country. Funke and Kennedy (1997, Table 8) report that in 199248 percent of world exports were denominated in dollars, down from 56 percent in 1980 (all of the drop and then some can be explained by the drop in the share of oil in world exports). This compares with a US share in world exports of 12 percent. Sixteen percent of world exports were denominated in German marks (up from 14 percent in 1980), compared with a German export share of 11 percent. The Japanese yen accounted for five percent of export invoices (up from 2 percent in 1980), compared with Japan's 9 percent share of world exports.

Funke and Kennedy (1997, Table 7) report the currency of denomination of international bonds and other international long-term lending (mainly syndicated bank loans), reproduced here as Table 1. Dollars accounted for 43 percent of the bonds in 1996, about the same as 1980, but up and down in the meantime. German marks actually declined during this period, from 22 percent to 14 percent, with yen, pounds, and French francs all showing increases. The Ecu rose to 8 percent of all new international bond issues in 1990, but then declined to less than one percent in 1996. 
Globalization of patterns of investment suggest that more and more national portfolios will be diversified, both geographically and across currencies. Thus this particular use of national currencies is likely to extend to many currencies, not just those of the major countries, including for example the Australian dollar and the South African rand, and eventually the Chinese yuan and the Russian ruble. Whether the diversification takes place into national or international bonds will depend on many issues, including yield, covenants, quality of secondary markets, transparency of information, reliability of the system for settling disputes, etc. But increasing cross-currency diversification of portfolios will be a natural consequence of globalization of information and ease of transactions. The major currencies can all expect to experience a secular decline in share, within rising totals.

International lending other than bonds was 77 percent in US dollars in 1996, down from 93 percent in 1980 (a year of high dollar deposits in the banks by oil-exporting countries, the peak year of oil revenues). The DM, yen, pound, and French franc all gained in share. More dramatic by far than changes in the currency composition of international lending, however, was the growth in the total, from $\$ 116$ billion in 1980 to $\$ 1059$ in 1996, so all major currencies, including the dollar, experienced a rapid increase in international use. While data are not readily available, currencies used for loan transactions presumably roughly followed the currencies of denomination, although not exactly (as is evident for ECU lending). For instance, in April 199584 percent of global gross foreign exchange market turnover involved the US dollar on one side of the transaction, leaving only 16 percent that did not involve the US dollar. This is strong evidence for the presence of network externalities, discussed above. Runners-up were the DM at 37 percent, the yen at 24 percent, and the pound at 9 percent (BIS, 1996). Many of these transactions were undoubtedly with 
the dollar. Since such transactions necessarily involve two currencies, total transactions add to 200 percent.

A vast and vigorous euro-currency market, based in London, has evolved from small beginnings in 1957 based on British banks accepting deposits and lending in US dollars. It has spread to several other currencies, based on British law and practice, and free from domestic regulation by the countries whose currencies are being quoted. The nearly $\$ 7$ trillion of assets in this market are difficult to interpret, since over 90 percent of them involve transactions among banks. Moreover, domestic de-regulation in many countries now permits local deposits in foreign currencies, confounding interpretation. It is suspected that many euro-bank liabilities in DM are actually to German residents, who hold their funds abroad to escape German taxation. At the end of 1996, at least 46 percent of all foreign deposits in the euro-currency market reported by industrial country banks were denominated in dollars, 15 percent were in DM, and 6 percent were in yen (BIS, 1997, Table 4A). Roughly the same ratios hold for the much lower deposits by non-banks: 51,17 , and 5 percent, respectively. The Italian lire and the French franc were close behind the yen. The existence of the euro-currency market reminds us that the use of a national currency can be detached from the nationality of financial institutions and even, to some extent, from national monetary authorities.

National governments or central banks held a total of $\$ 1481$ billion of foreign exchange in their official reserves at the end of 1996. Of this, at least 64 percent were denominated in US dollars, 14 percent in German marks, 6 percent in yen, 3 percent in pounds, and lesser shares in other currencies (from IMF, Annual Report, 1997, Table I.2). The dollar share was down substantially from the 79 percent of 1975, but showed a marginal increase (especially in developing 
countries) over the past decade. Again, these shares must be assessed in the context of a substantial increase in reserves over time, up from $\$ 716$ billion in 1989 and $\$ 373$ billion in 1980 . Alterations in share occurred within a rapidly rising total. Eighty percent of the increase in reserves in 1996 was in US dollars, ten percentage points of which were changes in valuation (IMF, Table I.3). The fact that US short-term interest rates were higher than those in other major countries (except for Britain) may have played a role in recent preference for the dollar.

Finally, it should be noted that national banknotes, especially the US dollar, are used extensively outside the issuing country. It is the nature of such holdings that they cannot be known with precision. But over half US currency by value is in the form of $\$ 100$ bills, rarely seen within the United States. The Federal Reserve has estimated that 55-70 percent of US banknotes in circulation, $\$ 373$ billion at the end of 1995, were outside the United States (Porter and Judson, 1996). German marks are much less extensively used, but are common in the former Yugoslavia.

\section{$\underline{\text { Impact of the Euro }}$}

The previous section has provided empirical information on the state and recent trends in international use of national currencies. Creation of the euro will represent a major "disturbance" to the international financial system. Will it affect international use of national currencies in ways beyond the obvious one, viz. the international uses of the DM and the French franc (and maybe the pound) will disappear? Some authors have argued affirmatively, that the very scale of the EMU, even at its smallest, certainly at its largest, will induce a major reassessment by traders, investors, and central banks around the world, leading to an international use of the euro under the various headings that will substantially exceed the current international use of existing EU currencies. 
As noted at the outset, Bergsten foresees a major international portfolio shift of $\$ 500-1000$ billion into euros during the first five to ten years of its existence; most of the shift will come out of dollars, $\$ 100-300$ billion from official reserves, the remainder from private holdings. This analysis takes as its starting point the prospective economic size of the EMU and its importance in world trade. The 15-nation EU has a slightly larger GDP than the United States, and also slightly larger foreign trade (excluding intra-EU trade). Excluding Britain and Sweden reduces both to somewhat smaller than the United States, but still roughly the same magnitude. The analysis goes on to argue that while European capital markets are now generally smaller and less well developed than those of the United States, this deficiency is likely to be made up during EMU's formative years. The United States has a large current account deficit, compared with a modest surplus for the European Union, and a large net debtor position, requiring eventual depreciation of the dollar to improve the trade balance in order to service the growing external indebtedness. Table 2 (from Prati and Schinasi in Masson et al., p.266) offers some comparative statistics for USA, Japan, $\mathrm{EU}(15)$, and $\mathrm{EU}(11)$.

The Maastricht Treaty's emphasis on price stability assures a reasonably firm monetary policy, and a stable unit of value. Finally, Europe is likely to experience some fiscal expansion during the early years of EMU, which, combined with firm monetary policy and fiscal contraction in the United States (aimed at balancing the Federal budget by 2002), will assure a prospective appreciation of the euro against the US dollar. For all these reasons, the euro will be an attractive vehicle for third parties, and even for Americans, to acquire.

Absent major policy failure by the United States, Bergsten expects the dollar to remain a leading world currency, but he also expects the euro to come to rival it in importance, suggesting 
that after a decade about 40 percent of "world finance" will be held in euros, 40 percent in dollars, and 20 percent in yen and other currencies.

Alogoskoufis and Portes (1997) also foresee that "the euro will substitute to a large extent for the dollar as an international means of payment, unit of account and store of value," although they do not attempt to estimate the magnitude of the shift. They point out that if such a shift is to occur, euro-denominated assets will have to be provided to the rest of the world on a net basis, and this will require (other things equal) a current account deficit by the EMU-countries on a continuing basis, achieved by an appreciation of the euro relative to the dollar and other foreign currencies, such as the yen (see also Cooper, 1992). Provision of euros through a current account deficit is possible, but not necessary. Short-term claims could also be provided through exports of long-term financial capital from Europe, in effect purchasing long-term assets for short-term liabilities to the rest of the world, much as the United States did during the 1950s and 1960s. In such an eventuality, the euro would not necessarily have to appreciate. So what occurs will depend not only on the institutional changes within Europe and on the attractiveness of the euro to the rest of the world, but also on how portfolio preferences of Europeans evolve. That, of course, will inter alia depend on relative yields; low interest rates in Europe are more likely to induce a search for higher-yield claims on the rest of the world, obviating the development of a current account deficit; by the same token, however, low interest rates on euro-denominated assets, relative to yields on alternative liquid assets, will reduce their attractiveness to foreigners.

Why the Euro will not replace the dollar anytime soon

As noted, it is useful to draw distinctions among the different roles that a money performs. 
But "money" is only part of the story, a convenient unit of account. The terms "dollar" and "euro" are really short-hand, metaphors for a more complex set of phenomena. One does not hold "dollars," but dollar-denominated assets, or banknotes (greenbacks). If substantial balances are to be held, there must be a convenient medium for holding them. The great strength of the British pound in the 19th and early 20th centuries was not only that Britain was the world's largest trading nation and that British trade was largely denominated in sterling. London was also the world's preeminent financial market. Within the City developed a highly liquid, highly efficient secondary market in outstanding bankers' acceptances and short-term Treasury bills. The same may be said currently of the US Treasury bill in New York and elsewhere. Amounts measured in billions of dollars can be bought or sold readily, 24 hours a day, anonymously, without influencing the price of the outstanding bills. In effect, for large holders the T-bill has become interest-bearing money. It can be converted into means of payment at virtually no cost. Government securities dealers had daily transactions in T-bills of $\$ 40-50$ billion.

The liquidity of the US treasury bill market is abetted by the Federal Reserve, which carries out its open market operations largely in treasury bills or other short-dated government securities. At the end of 1996 there were $\$ 777$ billion in US Treasury bills outstanding, and another $\$ 2112$ billion in Treasury notes with original maturities under five years, many of which at any moment in time will mature in less than a year. The Federal Reserve during 1996 added only $\$ 17$ billion to its stock of Treasury securities, but it had repurchase agreements valued at $\$ 458$ billion during the year. Moreover, the Federal Reserve in effect made a perfectly liquid market for foreign official monetary authorities by buying and selling T-bills offmarket in matched transactions (mainly overnight) that totalled $\$ 3092$ billion, an average of nearly $\$ 12$ billion per working day. 
There is nothing comparable to this market on the European continent, or in Japan, and there is not likely to be for decades to come. ${ }^{1}$ The German government, influenced by legal limitations, has eschewed short-term debt, which at the end of 1996 was only 4 percent of marketable Federal government securities, amounting to 27 billion DM (about $\$ 16$ billion); Germany also lacks a uniform contract for futures transactions (Prati and Schinasi in Masson et al., 1997).

France has the most effective short-term financial market on the Continent, but it relies heavily on repurchase transactions by the Bank of France, thus works mainly with the knowledge and approval of the Bank of France, with respect to securities acceptable to the Bank of France. Outright Bank of France purchases of treasury bills are low. As in Germany the treasury bill market is poorly developed, although its use has grown since it was introduced in 1985. Short-term government securities amounted to the equivalent of about $\$ 50$ billion at the end of 1996 -- 8 percent of marketable government debt. The share rises to 30 percent if 2- and 5-year notes are included.

In short, the European market is now small and fragmented. Introduction of the euro will of course eliminate currency differences among the participating Europeans countries, but that alone will not create a highly liquid secondary market in securities. That will not occur without a consolidation of outstanding government debts (as of, say, end 1991) under EMU responsibility, something that seems to be prohibited by the Maastricht Treaty, and indeed would be anathema to citizens in the fiscally conservative countries. Ironically, the Stability Pact will slow the development of a highly liquid euro-denominated asset, by limiting the extent to which European governments issue debt through budget deficits. Thus national government debt will grow only slowly after the introduction of the euro. Even if Germany were to run the full three percent of GDP 
budget deficit normally permitted by the Stability Pact, that would increase total outstanding German government debt only five percent a year. Only a drastic shortening of the average maturity, something Germany's debt managers -- and the Bundesbank -- would resist strongly, would permit the emergence of a euro-based competitor to the US treasury bill market. The German government inaugurated two new debt instruments in 1996: 6-month bills and 2-year notes. Of the largest ever net public borrowing by the Federal government of 83 billion DM in 1996, 23 percent was at relatively short term. But agreement with the Bundesbank limited outstanding "bubills," with less than one-year maturity, to a maximum of 20 billion DM (Monthly Review, March 1997, p.29).

A preference by monetary authorities for marketable securities over bank deposits is suggested by the fact that DM-denominated reserves in the form of deposits fell from over half in 1990 to barely one-third in 1996, involving an absolute fall in deposits within a growing total, as marketable securities became available. Having a common currency does not by itself assure a widely accepted and liquid store of value. America's states typically issue short-term tax anticipation notes; but the market for them is fragmented and for large transactions and for most states they are relatively illiquid on secondary markets despite their short-term maturities; their acceptability and hence liquidity is also influenced by tax considerations since, as in Europe, state taxation of interest-bearing securities is a matter left to the states, and they have quite different definitions of taxable income.

Liquidity of a financial instrument is subject to "network externalities" -- the more agents who have the security, and the more frequently they trade them, the more liquid the security is likely to be. This factor is likely to be more important than economies of scale in the choice of a currency for international use, since Europe and Japan, as well as the United States, have sufficiently large 
domestic markets to achieve any likely technical economies of scale (e.g. indivisibilities in setting up a clearing system) involved in running a monetary and financial system. Where network externalities are involved, they tend to be self-reinforcing. The product in question is very difficult to dislodge, short of a major shock to the network. The creation of the euro creates an important alternative, but by itself it is not likely to provide a shock large enough to dislodge the US Treasury bill from its international role. Its wide acceptability and its convenience are too great. ${ }^{2}$

Any holder of a financial asset has to assess several different kinds of risk: credit risk (that the issuer will fail), market risk (that interest rates will move sharply and unexpectedly), exchange rate risk (that exchange rates will move sharply and unexpectedly), liquidity risk (that the asset cannot be converted quickly to means of payment when needed). Credit risk is lowest for governments, especially those with access to a central bank. Market risk is lower at short maturities. Exchange risk is higher for a currency different from the one needed to make payments, but it can be hedged. The US Treasury bill market is low risk on all counts, except where external debt or imports are not denominated in dollars.

Similar observations might be made with respect to US banknotes -- greenbacks -- especially the $\$ 100$ bill. They are widely recognized and widely acceptable around the world, making them deeply rooted because of the externality involved. Money traders anywhere are even adept at identifying counterfeits. Over $\$ 200$ billion in US banknotes are estimated to be circulating outside the United States. This total is likely to continue to grow even after introduction of euro banknotes in 2002, except where cash expenditures by European travelers are overwhelming, as German use of DM was in the former Yugoslavia -- possibly in the central and eastern European countries, all aspirants to future EU membership, and in North Africa. ${ }^{3}$ 
The willingness to hold interest-bearing assets is of course influenced inter alia by their yield. It has not hurt the role of the dollar in recent years that short-term interest rates on US securities have exceeded those on DM assets, which in turn have exceeded the all-time low yield below 0.5 percent on short-term yen assets. Economists often argue that persistent yield differences on low-risk assets of comparable maturity must reflect expected movements in exchange rates, prospectively compensating for the differences in yield. That may be so, but forward exchange rates, which typically reflect yield differentials accurately, are notoriously poor (and biased) forecasters of future spot rates. In short, exchange rates typically do not move as yield differentials would suggest. This should not be entirely surprising. As noted above, at least some private balances in foreign currencies are held for their usefulness in transactions and for their liquidity. The owners do not necessarily expect to hold their balances for long enough for expected changes in exchange rates to come into play; while aggregate totals may grow, they reflect a continual change in ownership. Moreover, while the risk of depreciation is constantly present, depreciation may not actually materialize for an indefinite period. Nonetheless, a change in relative yield would influence the aggregate holding of foreign currency balances, partly by influencing the timing of their acquisition and disposition.

In this context, the historical switch from sterling to the dollar as the leading international currency shows only that such a switch can happen, not that it is likely to happen. Bergsten (1997) has emphasized the similarities between the dollar's overtaking the British pound and the possibility of the euro's overtaking the dollar, notably the relatively larger and growing size of the emerging currency's economy in each case, and the switch from a net creditor to a net debtor position vis-a-vis the rest of the world by the incumbent currency's economy. But one can just as well, and more 
pertinently, emphasize the important differences between the pound-dollar switch in the 1930s and 1940s and the prospect of a dollar-euro switch in the early 21 st century. First, Britain's economy and its overseas financial position had been devastated by two World Wars. Second, the large external sterling balances accumulated during and shortly after the Second World War were reluctantly held because they could not be used freely for importation, in some years even from Britain. Third, exchange controls sharply limited the use of sterling in financing third country trade (i.e. trade not involving Britain or sterling area countries). In short, sterling was highly limited in its usability. Such is not the case with the dollar today, or for the foreseeable future. There is a large difference between a currency reluctantly held and one that is voluntarily held, as the dollar is; not surprisingly, the latter is preferred to the former, and holders of sterling switched as soon as they could gracefully do so.

The creation of the euro will eliminate the current international use of those European currencies which are subsumed by the euro. Since the bulk of DM holdings are undoubtedly held by residents of member countries of the European Union, their replacement by euros, which will no longer be "international" currency for the members of the EMU, will paradoxically increase the relative international role of the dollar and the yen. But that is a statistical artifact.

What is not a statistical artifact is that many foreign exchange reserves now held by European countries, for defense of their currencies in foreign exchange markets, will become redundant after creation of the euro. Estimates of redundancy vary, since our understanding of the official demand for reserves remains imperfect, but Leahy (1994) has produced a not-veryconfidently held average redundancy of 35 percent. If EMU members were to unload these reserves, mainly dollar-denominated, that would exert a major impact on foreign exchange markets, 
appreciating the euro relative to the dollar. But partly for this reason, partly because central bankers hate to part with reserves once they have been acquired, EMU members are not likely to unload their redundant reserves quickly, or indeed even at all until circumstances call for their use, e.g. to prevent unwanted depreciation of the euro.

\section{$\underline{\text { Some remarks on the Japanese yen }}$}

The observations about short-term markets in euro-denominated securities applies even more to yen-denominated assets. For a variety of reasons, mainly having to do with the desire to borrow at preferential interest rates, the Japanese government declined for decades to develop a marketpriced treasury bill market (see Ito, 1992). It crossed that hurdle in the early 1990s, but the market remains small and relatively undeveloped. Securities transactions are plagued by both regulations and taxation. Japan traditionally has focussed its financial market around the leading banks. They issue CDs, but the secondary market is not well-developed, except for repurchase agreements. In any case, as the world has learned during the last decade, even the largest commercial banks carry some credit risk, and in the mid-1990s the large Japanese banks were down-graded in their access to the world's interbank markets. So while large bank CDs represent a possible vehicle for holding yen-denominated assets, they are less satisfactory than short-dated government securities.

The inflexibilities and limitations of the Japanese financial market may be about to change. The Japanese government is committed to major financial reforms during the next five years. As of April 1998 the Foreign Exchange Law (placing institutional restrictions on who in Japan can deal in foreign currency) has been repealed. Many other changes are envisioned, with a view to making Tokyo a financial market that can compete effectively with London and New York. It remains to 
be seen whether the planned changes will be implemented and, if implemented, whether they will be executed in the spirit of the current plans -- that is, whether Ministry of Finance (MOF) officials will in fact maintain some distance from the operations of financial institutions and markets, and whether Japanese institutions can function well in the absence of continuing guidance from the Ministry of Finance.

The main impact of the financial reforms will be on residents of Japan, who will enjoy greater competition in financial markets, leading to greater choice, higher yields, and lower costs. But the increased competition and reduced regulation will make short-term transactions in Tokyo's financial market more attractive to foreigners as well.

The plans for financial reform are silent on the question of government securities, partly no doubt because the MOF badly wants to reduce the budget deficit, and is loath to relinquish its preferred position with Japanese institutional investors. And while plans acknowledge the importance of revising the tax laws as they pertain to financial transactions, no concrete plans for change have been advanced -- reflecting, no doubt, a reluctance to make any changes that may reduce revenue.

Thus the international role of the yen as a temporary store of value is limited, and is likely to remain so for at least another decade. What happens beyond that depends on how successful are the ambitious plans for financial market reforms. Even then, growth of the yen's role will be limited by the network externalities associated with the dollar discussed above. Moreover, the relative size of the Japanese economy in the world economy is likely to decline slowly, because of low labor force growth in the decades ahead; Japan's relative economic importance may have reached its peak in the late 1980s. Growing Japanese investment in Asian countries, often farming out labor- 
intensive slices of the production process, will doubtless encourage greater international use of the yen, not only by Japanese firms operating abroad, but also by their suppliers and perhaps also their non-Japanese customers. But the growth is likely to be slow, and not much affected by the creation of the euro.

Consequences of a euro-based international monetary system

The conclusion of the foregoing discussion is that the euro will not come to rival the dollar seriously in its major international roles for many years to come, perhaps decades, beyond the obvious substitution of euro-denominated assets and invoices for assets and invoices now denominated in various national European currencies.

But suppose this prognostication about an always uncertain future were wrong. What differences would it make? Try to imagine a future in which many or most of the current international roles of the dollar are played by the euro.

The first point to note is that the EMU countries together will have large interest payments to foreigners. That by itself will require some depreciation of the euro, relative to what it would be otherwise, in order to generate the trade surpluses required to make the interest payments. So long as world demand for foreign exchange assets is growing, however, the rest of the world will steadily increase its investments in euro-denominated assets, and ceteris paribus that will tend to appreciate the euro. The net effect of these conflicting tendencies will depend both on the level of interest rates and on the rate of growth in rest-of-world holdings of euros. So long as the growth in world demand for euros exceeds the rate of interest paid on them, the net effect will be to appreciate the euro more than otherwise. 
Second, short-term interest rates in high-quality euro securities will be modestly lower than otherwise, because of the world demand for international liquidity, and short-term interest rates on dollar securities will be somewhat higher. Third, pride of French and some Brussels officials will swell, while pride of some US Treasury officials will be deflated.

Apart from these effects, however, the world will function pretty much as it does today. Some things will not be radically different. In particular, the United States will not find it markedly more difficult to finance current account imbalances, nor will Europe find financing of current imbalances markedly easier. The ease or difficulty of such financing depends above all on the size of the economies involved, on the development of their financial markets, and on public perceptions of skill in managing them, which together influence access to the world capital market. The Europeans will not have a greater voice than they now do in discussions of world economic management, although on some issues they may speak with greater coherence. Europe will not experience an improvement in its terms of trade by virtue of invoicing international trade in euros. The constantly changing dollar price of oil responds to world shifts in demand and supply of oil, not to the fact that it is denominated in dollars rather than yen or marks. Similarly for other commodities.

Europeans will probably pay less attention to the dollar exchange rate than they do today, and for that reason European monetary authorities might take a stance of benign neglect toward the exchange rate. If the US authorities continued to do the same, the result might be greater volatility in exchange rates between the dollar and the euro than has been the case between the dollar and the various European currencies. On the other hand, the US authorities, faced with a single most significant exchange rate, might take a more active view toward both the appropriate level and the 
variability of that exchange rate, and thus manage the rate more aggressively than they have in the past. Thus the US and the European roles would be reversed in this respect, and the United States among other changes would want to hold more foreign exchange reserves (mainly in euros) than it has done historically.

Of course, by assumption, the rest of the world would be holding most of its foreign exchange reserves in euros. This last point reminds us that to get to this state there is likely at some point to have been a substantial conversion of foreign-held dollars into euros. That process, rather than the end result, might create major disturbances for the world economy, causing, if it occurred rapidly, major changes in both exchange rates and in interest rates in the United States and Europe. Thus potential turbulence lies

much more in the transition than in the final configuration.

\section{$\underline{\text { Important neglected issues }}$}

The foregoing discussion has focussed on the impact of the euro on the international role of the dollar and other currencies. There are several other implications, possibly more important, arising from creation of the euro. ${ }^{4}$ The first concerns "balance of payments" adjustment within Europe and its implications for European attitudes toward trade protection. A second concerns the mechanics of international cooperation in exchange rate management. A third concerns the desire of the new ECB to establish its reputation in the early EMU period for being a tough inflation fighter and for being independent of government.

Adjustment to disturbances within Europe may not take place smoothly for many years after the introduction of EMU, due to incomplete price and wage flexibility and imperfect labor mobility 
within Europe. Indeed, this is the outcome most feared by many opponents of EMU, and even by some of its proponents (see Obstfeld, 1997, and references there cited). Monetary union postulates an adjustment mechanism that relies on price and wage flexibility, and ultimately on labor and capital mobility within the geographic domain in question. (An alternative compensating mechanism, to avoid adjustment, involves subventions from some regions to others, and is taken up below.)

The need for adjustment cannot be avoided in any dynamic economy, subject as it is to changing patterns of demand and output, driven ultimately by continuing technical change. If the adjustment process works poorly, some regions will be depressed for long periods, and others will experience booms. A regional boom will generally arise from outside demand for the region's exportable products, and that will both increase the region's imports and lead to bidding up the prices of local factors of production and non-tradable goods and services, for which import competition is limited. At the same time, regions experiencing a decline in export demand will see a decline in their incomes and imports, and downward pressure on the prices of local factors of production and non-tradable goods and services. Whether prices actually decline in response to that pressure depends on their flexibility, i.e. on the extent of nominal wage and price rigidity, something that is common in modern economies.

The effect of all this on the rest of the world depends on how economic policy-makers respond. If price increases in the booming regions are interpreted as "inflation" (which they would seem to be if not compensated by actual price reductions in the relatively depressed regions), the monetary authorities might tighten monetary conditions, which in turn would appreciate the euro against non-member currencies. Both tighter money and a stronger currency would dampen 
aggregate demand, leading the members of EMU to an overall condition of stagnation (which does not exclude that a few regions are still booming, although less so than before the policy response). Effective inter-regional adjustment requires allowing the price mechanism to work, which means allowing prices of non-tradables to rise in booming regions.

If in contrast the monetary authorities ease monetary conditions to relieve the depressed regions, the EMU as a whole will experience demand-led growth, in part through real depreciation of the euro, and greater inflation -- a course that the commitment to price stability would seem to rule out. Either way, the rest of the world will feel the impact of these responses to imperfect regional adjustment.

Adjustment can be mitigated or avoided altogether if depressed regions are subsidized by booming regions. Drawing on the alleged experience of the United States, it is often said that interregional fiscal transfers greatly cushion regional imbalances, with the implication that the European Union should greatly augment such transfers as it moves toward monetary union. ${ }^{5}$ It is of course true that in the United States Federal government expenditures and Federal taxes are substantial, roughly 40 percent higher than the aggregate tax collections of the state and local governments. It is also true that when income in a region declines, its contribution to Federal taxes (the most important of which is income taxes) declines, while at the same time Federal expenditures in the region are not likely to decline, and through some limited programs may actually increase. ${ }^{6}$ The reverse occurs in a booming region: Federal tax payments rise, while expenditures are not likely to rise (unless an autonomous increase in Federal government expenditures is the source of the boom). This response reflects the "automatic stabilizer" role of modern tax systems, linked to corporate and personal income, and to employment in the form of payroll taxes. 
But this automatic stabilizer exists in any modern fiscal system, even for the whole country. It is not limited to federal systems. When economic activity slackens, tax revenues fall. Unless government expenditures are consciously cut in response to the fall in revenues (as, unfortunately, might be required under Europe's Stability Pact), the budget provides an automatic cushion to a decline in activity. Of course, the government must borrow more to cover its enlarged deficit, taking on an obligation against the future income of all its citizens. For a region within a country, this obligation does not fall on its residents alone, but rather is spread over all the residents of the country. One would have to believe in a strong form of Ricardian equivalence, however, to suppose that this difference is crucial to the cushioning impact of the government sector on current income and output. ${ }^{7}$

While some US states are net recipients of federal funds and others are net contributors to federal funds on a continuing basis, and those net flows are to some extent related to income differentials among regions, what is relevant for inter-regional payments adjustment is the cyclically sensitive component of federal expenditures: do such (net) expenditures increase as a result of relative decline in regional activity, and do they decline in a booming region? In reality, the interregional transfers (taking into account both taxes and expenditures) sensitive to transitory shocks are quite low in the United States. Von Hagen (1992) estimates them at only 0.1 percent of the change in state income. Most of the substantial cushioning effect does not involve inter-regional transfers, but rather the sensitivity of tax revenues to economic activity that exists in most modern economies. Nonetheless, lower labor mobility in Europe than in the United States may warrant greater reliance on inter-regional fiscal transfers to cushion regional payments imbalances. The Union has not yet addressed this issue squarely. 
A second point concerns international cooperation in exchange rate management. As noted above, free floating between the US dollar and the yen and the euro is likely to lead to more volatility of exchange rates than has been true under the managed floating of the past. Suppose authorities would like to damp this volatility through official action, which typically works better if the actions are undertaken cooperatively (Dominguez and Frankel, 1993), or even nudge the exchange rate back toward more acceptable levels, as has happened on occasion during the past 12 years.

Imagine sitting in Washington or Tokyo or Ottawa after 1999. With whom exactly does one consult on exchange rate policy in post-EMU Europe? Historically, discussions on exchange rate cooperation have occurred within the G-7 setting, i.e. finance ministers and their deputies. But under Maastricht the ECB will have full control over exchange rate policy (as distinguished from choice of the exchange rate regime, which remains the responsibility of governments). Ministers have responsibility for other aspects of macro-economic policy (except of course monetary policy). But much cooperation in the past has focussed on exchange rate management. The ECB president presides over a committee in which he has only one vote, and in any case it would be anomalous for him to attend an international meeting of finance ministers. Without a clear interlocutor for exchange rate policy of the euro, international cooperation will be difficult. This has not been a problem to date, since finance ministries everywhere have responsibility for exchange rate management, with responsibility being somewhat ambiguous and a source of continuing tension in Germany. ${ }^{8}$

Third, once the new ESCB is created and endowed with monetary authority, it will be concerned with establishing a reputation for "sound" monetary policy, especially with a skeptical 
German public, which will be uneasy about passing monetary authority from its respected Bundesbank to a new, untried institution. The ECB thus will be tempted to pursue a monetary policy that is tighter than required, and than would be pursued by a monetary authority whose reputation was secure. Tight monetary policy could possibly be rationalized by the conviction that fiscal policies in the member states are too "loose", even when governments must finance their budget deficits in the capital market rather than at national central banks, which by now will cease to have money-creating powers. This combination will for a time ensure a "strong" euro in international markets, with corresponding depressing effects on European export competitiveness and its associated impact on the rest of the world.

\section{$\underline{\text { Conclusions }}$}

This paper has reviewed the forms of and reasons for the international use of national currencies. It concludes that while the creation of an Economic and Monetary Union in Europe, with its own currency the euro, will mark a major event in the annals of monetary history, and will require major changes within Europe, it is not likely to affect much for many decades the international monetary system outside Europe, and in particular the international uses of the US dollar. The main reasons have to do, first, with the deeply entrenched network externalities associated with convenience, familiarity, and widespread use of the dollar by others; and, second, with the fact that the euro by itself is only a unit of account, not an instrument in which investments can take place. It will be many years, even decades, before Europe has a financial instrument that can rival the US Treasury bill in its universality of acceptance and in its liquidity. Unless economic and financial developments in the United States take such a disastrous turn that they cast doubt on 
the reliability of the T-bill, the dollar is likely to retain its pre-eminence as an internationally recognized short-term store of value and a transactions currency for decades to come. In time, the euro will no doubt become an important international currency, but the process is likely to be gradual; moreover, in the context of a growing world economy, the euro will supplement rather than directly displace the dollar in its diverse international roles.

The creation of EMU will have important implications for the world economy. But they lie more in the uncertainties concerning intra-EMU balance-of-payments adjustment and the implications for international cooperation of the awkward division of responsibilities under the Maastricht Treaty than in likely displacement of the dollar in its major international uses.

\section{$\underline{\text { Endnotes }}$}

1. On German financial markets, see various issues of the Monthly Report of the Bundesbank; on French financial markets, see Bruneel 1992, Banque de France 1994, and CNCT 1997; on Japanese financial markets in the early 1990s, see Ito 1992.

2. The presence of network externalities gives rise to the possibility of multiple equilibria, which if strongly stable require a major disturbance to generate a switch from one equilibrium to another. This phenomenon can be observed in many settings, such as the continuing dominance of the (inefficient) QWERTY keyboard for typewriters and now for computers; the continuing dominance of Microsofts' DOS operating system and its descendants in personal computers; the growing dominance of English, a relatively complicated (but tolerant) language, as the language of world commerce and diplomacy, etc. For a discussion of multiple equilibria in the context of international currencies, see Rey (1997); in the context of language (in a Canadian setting), Church and King (1993).

3. The Bundesbank has estimated "conservatively" that about 16 billion DM (roughly $\$ 10$ billion) in German banknotes are held outside Germany. Bundesbank Monthly Report, April 1997.

4. The subsequent discussion draws on Cooper (1992).

5. See, e.g., Eichengreen (1990); the Delors Report mentions the need for greatly increased "structural funds" to help correct regional imbalances. At Maastricht Spain insisted on and received formal assurances on the need for a large increase in funds to go to the four poorer countries of the Community. This criterion, however, is not at all the same as that calling for centrally-allocated 
funds to assist in adjustment to latent regional imbalances in payments.

6. Unemployment compensation in the United States is financed by each State. If necessary, loans from the Federal government are made, but must be repaid. Under certain circumstances, usually involving a national recession, the Federal government may contribute to unemployment compensation beyond the 26 weeks normally allowed.

7. Under the extreme form of Ricardian equivalence, private savings would rise to match the future debt obligations. This rise in private saving would neutralize fully the cushioning effects of any government deficit on aggregate demand in the country as a whole, but would only reduce them for a particular depressed region which did not have to carry the entire burden of the increased debt associated with any increase in the overall budget deficit. Increased saving in other regions would reduce its exports, however, and on that account would worsen its condition. Of course, if a rise in federal tax revenues arose because of a regional boom elsewhere, there need not be any increase in its overall budget deficit.

8. Article 109(2) of the Maastricht Treaty provides that apart from formal agreements with nonmember countries the Council of Ministers "may formulate general orientations for exchange-rate policy for these currencies. These orientations shall be without prejudice to the primary objective of the ESCB to maintain price stability." Since the ESCB will be the sole judge of what is required for price stability, any such guidelines from the Council will only be hortatory. 


\section{References}

Bank for International Settlements, Central Bank Survey of Foreign Exchange and Derivative Activity, Basle, May 1996.

Bank for International Settlements, International Banking and Financial Market Developments, Basle, quarterly, May 1997

Bergsten, C. Fred, "The Dollar and the Euro," Foreign Affairs, 76 (July/August 1997).

Banque de France, "Les Intraventions de la Banque de France sur le Marché Monétaire," Note d'Information No. 97, Février 1994.

Bruneel, Didier, La Monnaie, Paris: La Revue Banque Editeur, 1992.

Conseil National du Credit et du Titres, Rapport Annuel 1996, Paris: Banque de France, 1997.

Church, Jeffrey, and Ian King, "Bilingualism and Network Externalities," Canadian Journal of Economics, 86(May 1993), 337-345.

Cooper, Richard N., "Will An EC Currency Harm Outsiders?" Orbis, 36 (Fall 1992).

Dominguez, Kathryn M., and Jeffrey A. Frankel, Does Foreign Exchange Intervention Work?, Washington: Institute for International Economics, 1993.

Eichengreen, Barry, "One Money for Europe? Lessons from the United States," Economic Policy (April 1990), 118-187.

Funke, Norbert, and Mike Kennedy, "International Implications of the European Economic and Monetary Union," OECD Working Papers No. 174, Paris: OECD, 1997.

Henning, C. Randall, Currencies and Politics in the United States, Germany, and Japan, Washington: Institute for International Economics, 1994.

Ito, Takatoshi, The Japanese Economy, Cambridge, MA: MIT Press, 1992.

Leahy, Michael P., "The Dollar as an Official Reserve Currency under EMU," International Finance Discussion Papers No. 474, Federal Reserve Board, Washington, 1994.

Masson, Paul R., Thomas H. Krueger, and Bart G. Turtelboom, eds., EMU and the International Monetary System, Washington: International Monetary Fund, 1997.

Obstfeld, Maurice, "Europe's Gamble," Brookings Papers on Economic Activity, 1997, No.2.

Porter, Richard D., and Ruth A. Judson, "The Location of U.S. Currency: How Much Is Abroad?" Federal Reserve Bulletin, October 1996. 
Rey, Hélène, "International Trade and Currency Exchange," Centre for Economic Performance Discussion Paper No.322, London School of Economics, February 1997.

Von Hagen, Jürgen, "Fiscal Arrangements in a Monetary Union: Evidence from the U.S.," in Donald F. Fair and Christian de Boissieu, eds., Fiscal Policy, Taxation, and the Financial System in an Increasingly Integrated Europe, Dordrecht, Netherlands: Kluwer Academic Publishers, 1992. 